\title{
バウシンガー効果を考慮したダンパー用鋼材の簡潔な履歴モデル SIMPLE HYSTERESIS MODEL OF STEEL FOR DAMPER CONSIDERING THE BAUSCHINGER EFFECT
}

\author{
山田. 哲*1, 吉 敷 祥 一*2
}

Satoshi YAMADA and Shoichi KISHIKI

\begin{abstract}
Recently, steel with low yield point, such as LYP100 and LYP225, is used for damper. In this study, relationship between true stress and true strain of steel for damper is simply modeled considering the Bauschinger effect. This hysteresis model is composed of skeleton curve, Bauschinger part and unloading part. Skeleton curve corresponds to the stress-strain relationship of monotonic loading test. Bauschinger part is modeled as a function of the cumulative strain in the skeleton curve on the basis of experimental result of cyclic loading test. Though the hysteresis model is simple, it corresponds well to the experimental result. It is enough effective in order to analyze the behavior of dampers in the plastic range.
\end{abstract}

Keywords: Steel for Damper, Hysteresis Model, True Stress - True Strain Relationship, Bauschinger Effect, Energy Absorption ダンパー用鋼材、履歴モデル、真応力度-真丕度関係、バウシンガー効果、エネルギー吸収

1. 序

地震による入カエネルギーを部材の塑性歪エネルギーとして吸収 させる耐震極限設計 ”において、ランダムな繰り返し外力を受ける 部材の履歴举動を予測し塑性変形能力の評価を行うことは、部材の エネルギー吸収能力に基づく建物の耐震性能の評価を行う上での基 本となる。部材レベルにおける履歷挙動の予測と塑性変形能力の評 価を行うには、部材レベルでの実験結果を蓄積するだけでなく、繰 り返し応力を受ける鉿素材の履歴挙動を知っておくことも重要であ る。エネルギーの授受に着目した耐震極限設計の考えを発展させた 柔剛混合構造 ”や損偒制御構造 2)では、重力を支持する主架構を強 震下においても弾性範囲に留め、エネルギー吸収部材であるダンパ 一により地震に抵抗することから、地震荷重下におけるダンパーの 履歴挙動の把握は、建物の性能を評価する上での重要な前提となる。

任意の載荷履歴を受ける鋼素材の履歴挙動に関する研究はこれま でも数多く行われており ॐ〜 6)t苂、構築された鋼素材の履歴則の数值 モデルは発達した数值解析手法に適用されることで、鋼部材や鋼構 造物の弾塑性域にわたる履歴挙動を予測するための有力なツールと なっている。精緻な数值解析を行うためには解析で必要とする精度 に応じた精緻な履歴モデルが必要であるが、大局的に物理現象を理 解するためには、できるだけ簡単な表現であると同時に原理に忠実 なモデルを使うことが有効である。

既報 ”において、構造用鋼材の軸方向繰り返し載荷実験結果に基 づき、その真応力度-真丕度関係をバウシンガー効果を考慮した簡 潔な表現でモデル化した。この履歴モデルは、任意の載荷履歴を受
ける鋼素材の履歴曲線を、一方向載荷下における真応力度-真歪度 関係と対応する骨格曲線、既に経験した応カレベルでの負荷履歴で あるバウシンガー部及び弾性除荷部により表現した加藤・秋山・青

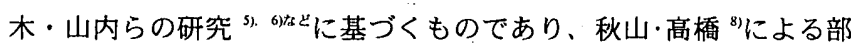
材レベルでの履歴モデルと対応するものである。本研究においては、 ダンパー用の鋼材である極低降伏点鋼 LYP100 および低降伏点鋼 LYP225 を対象に軸方向繰り返し載荷実験を行い、実験結果に基づ き素材レベルでのバウシンガー効果を考慮した簡潔な履歴モデルの 構筑を行う。また、同一の載荷履歴で行った極低降伏点鋼および低 降伏点鋼の実験結果を、既報”で行った SN400 の実験結果と比較し、 鋼種による履歴挙動の違いを考察する。

\section{2. 鋼材の軸方向繰り返し載荷実験と履歴挙動のモデル化 \\ 2.1 試験体}

試験体は図-1に示す形状を有し、板厚 $16 \mathrm{~mm}$ の鋼板から圧延方 向と載荷方向が一致するように切り出した。試験区間は中央平行部 $200 \mathrm{~mm}$ であり、試験区間両端の押さえ部には、試験区間の軸方向 長さの変化を計測するための変位計を接続する M12 全ねじ棒が点 付け溶接されている。試験区間の幅は、アタチュエーターの容量と 材料の強度の関係から、LYP100の試験体については 50mm、LYP225 の試験体については $40 \mathrm{~mm}$ とした。また、試験区間端部の仕上げ は $\mathrm{R}=0.25 \mathrm{~mm}$ とし、試験区間の平均応力度をできるだけ一定に保つ ようにした。

\footnotetext{
${ }^{* 1}$ 東京工業大学建築物理研究センター 助教授・博士 (工学)

Assoc. Prof., Structural Engineering Research Center, Tokyo Institute of

*2 東京工業大学 大学院生・修士 (工学) 
試験体に使用した鋼材の JIS-1A 号試験片による引張試験結果を、 図-2および表-1に示す。図中および表中の值は、公称応力度、公称 歪度である。本実験では、LYP100について 2 ロットの鋼材に対し 2 体ずつの 4 体、LYP225について 2 ロットの鋼材に対し 4 体ずつの 8 体、合計 12 体の試験体について、載荷履歴をパラメーターとした 実験を行った。このうち LYP100の試験体 4 体は、極低降伏点鋼の 歪速度依存性を調べるために行った実験 "において、準静的載荷の 条件で載荷した試験体である。試験体一覧および各試験体に適用し た載荷履歷を表-2に示す。載荷履歴は、規則的な漸增歪振幅と、ラ ンダムな歪履歷をイメージして染意的に作成したプログラム履歴で ある。L1_2_09 試験体、L2_1_04 試験体および L2_2_04 試験体に適 用したプログラム履歴を図一3に示す。載荷履歴の制御には、試験区 間における平均公称歪度を用いた。

\section{2 実験方法}

実験装置を図-4に示す。試験体の一端を反カブロックに固定し、 他端を平行移動装置を介して $500 \mathrm{kN}$ アクチュエーターに接続して、 準静的 $(0.01 \% / \mathrm{sec})$ 軸方向繰り返し載荷を行った。また、纴縮力下で の試験区間における座屈を抑えるため、試験体周囲には図-5に示す 面外変形拘束治具を設圈した。この治具は、試験区間において強軸、 弱軸ともに面外変形を拘束するものであり、試験体との間には摩擦 力の発生を防ぐために一定の隙間を設け、隙間にはテフロンシート を挟んだ。圧縮力下における試験区間での体積增加についても、こ の隙間とテフロンシートの変形で対応させた。

試験体に作用する軸力は、アクチュエーターヘッドのロードセル で計測し、試験区間 $(200 \mathrm{~mm})$ に生じる長さの変化は、LYP100 の試 験体については土 $20 \mathrm{~mm}$ 差動トランス型変位計により、LYP225の 試験体についてはバネ式 $50 \mathrm{~mm}$ 変位計により計測した。

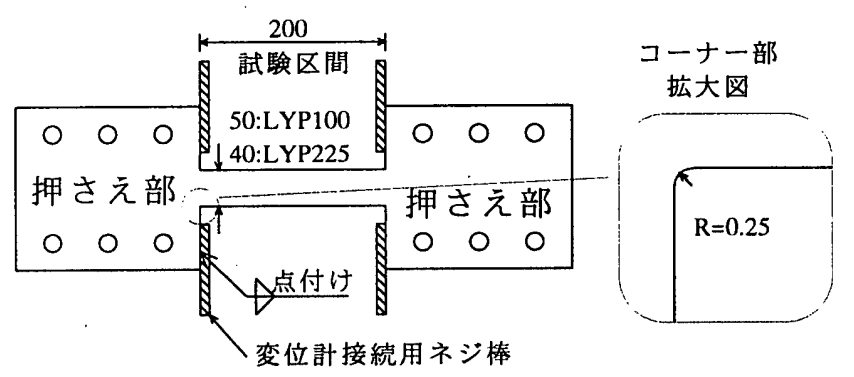

図-1 試験体形状

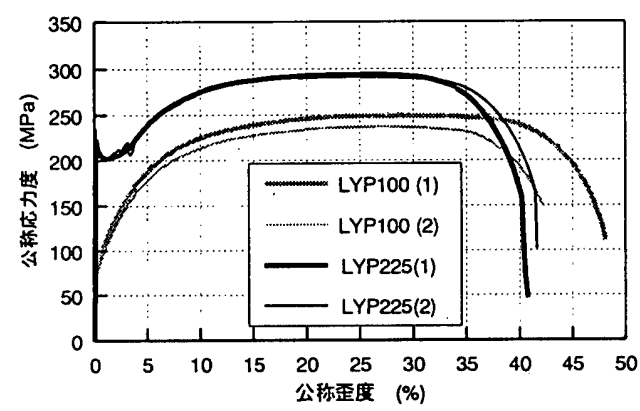

図-2 素材試験結果(公称応力度-公称丕度関係)
表-1 素材試験結果一臨

\begin{tabular}{|c|c|c|c|c|}
\hline 留材 & $\begin{array}{c}\text { 降伏強さ } \\
(\mathrm{MPa})\end{array}$ & $\begin{array}{c}\text { 引張強さ } \\
(\mathrm{MPa})\end{array}$ & 降伏比 & $\begin{array}{c}\begin{array}{c}\text { 破断伸び } \\
(\text { ( ) }\end{array} \\
\end{array}$ \\
\hline LYPIO0(1) & $83.6+1$ & 249 & 0.34 & 49.5 \\
\hline LYPI00(2) & 80.411 & 237 & 0.34 & 44.2 \\
\hline LYP 225(1) & $224: 2$ & 294 & 0.76 & 40.8 \\
\hline LYP225 (2) & 23512 & 291 & 0.81 & 41.6 \\
\hline
\end{tabular}

表-2 試験体および載荷履歴

\begin{tabular}{|c|c|c|}
\hline 武監体名 & 銅材 & 歪原歴 \\
\hline L1_1_01 & LYP100(1) & 昰振蜡で28,3\%,48の渐增垔振幅 各振幅で3回緗り返し载荷 \\
\hline LI_I_06 & LYPIO0(1) & 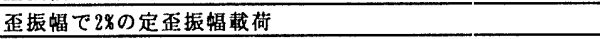 \\
\hline $11 \_2 \ldots 01$ & LYP100(2) & 雷振蝠で2\%，3\%，4\%の渐增垔振蝠 \\
\hline L1_2_09 & LYP $100(2)$ & プロクラム $($ 図 -3 参琞 $)$ \\
\hline L2_I_01 & LYP 225(1) & 歪振幅で0.5\%ことの渐增昰振幅 各振帽で2回緗り返し载荷 \\
\hline l.2_1_02 & LYP225(1) & 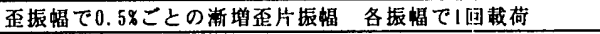 \\
\hline L2_1_03 & LYP225(1) & 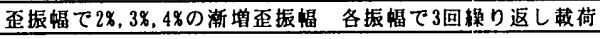 \\
\hline L2_I_04 & LYP225(1) & プログラム (図-3参照) \\
\hline L2_2_-01 & LYP225(2) & 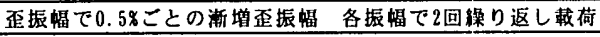 \\
\hline L2_2_02 & LYY 225(2) & 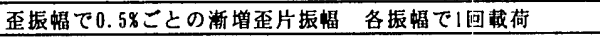 \\
\hline L2_2_03 & LYP 225 (2) & 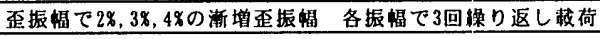 \\
\hline L2_2_04 & LYP225(2) & プロクララ (図-3参照) \\
\hline
\end{tabular}

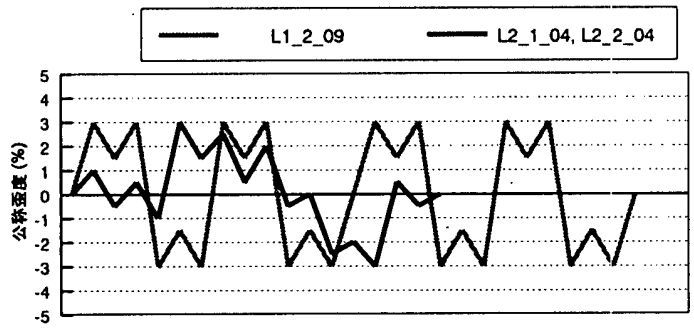

図-3 プログラム履歴

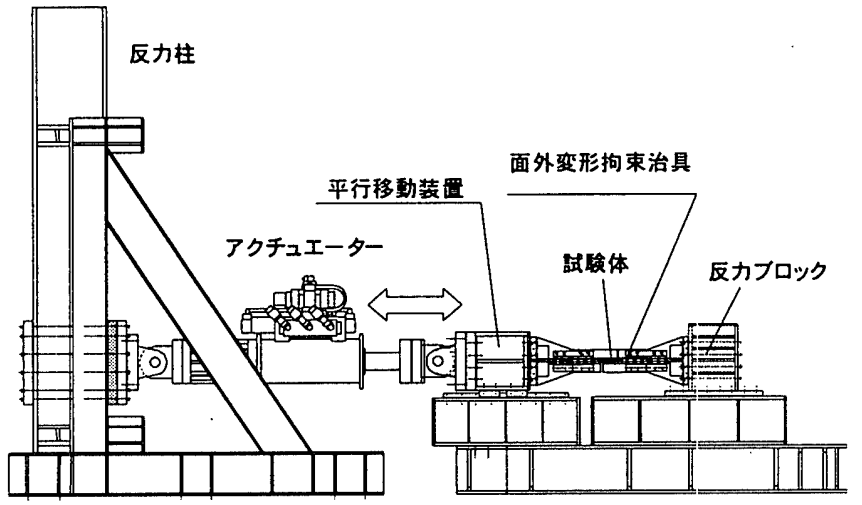

図-4 実験装圈

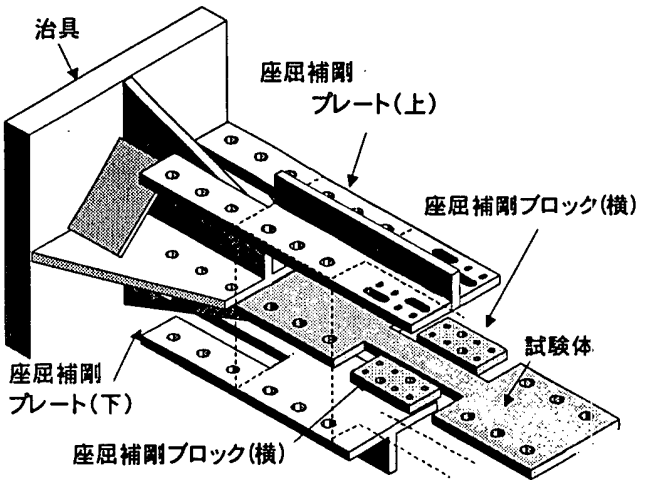

図-5 試験体の面外変形拘束 


\section{3 実験結果}

\subsection{1真応力度-真歪度関係}

試験体に作用する軸力を原断面積で、試験区間に生じる長さの変 化を元長さで除すことで、公称応力度-公称丕度関係 ${ }_{n} \sigma_{-n} \varepsilon$ 関係 $)$ を得 た。符号は引張側を正とした。これを、体積一定の仮定のもとで、 式(1),(2)により真応力度-真歪度関係(, $\left(_{-\Perp} \varepsilon\right.$ 関係)に置換した。

$$
\begin{aligned}
& { }_{1} \sigma=1+{ }_{n} \varepsilon ; \cdot{ }_{n} \sigma \\
& { }_{1} \varepsilon=\ln \left(I+{ }_{n} \varepsilon\right)
\end{aligned}
$$

\subsection{2 真応力度-真歪度関係の分解}

履歴モデルの構築を行うにあたり、まず真応力度-真歪度関係を、 図-6に示すように骨格曲線、バウシンカー部、弾性除荷部に分解し た。图-6中、 $E$ は弾性剛性、 $\Delta_{t} \varepsilon_{s}$ は各サイクルでの骨格曲線におり る塑性歪の増分、 $\Delta_{1} \varepsilon_{B}$ は各サイクルでのバウシンガー部における塑 性歪の增分である。骨格曲線は、圧縮：引張それぞれの領域におい て、初めて達する応カレベルにおける真応力度-真歪度関係の増分 をつなぎ合わせたものである。ただし、素材試験において上降伏点 に達した後応力の変動を伴う長い降伏棚が観察された LYP225 につ いては、初期降伏後、応力度の絶対值が正側について再び初期降伏 応力度を超えるまで、負側については初めて初期降伏応力度を越え るまでは、素材試験結果における降伏棚の最小応力度を越えた部分 を骨格曲線(降伏棚)と見なした。

\section{4 骨格曲線}

既往の研究 5. 6)好とにおいて、繰り返し載荷を受けた鋼材の真応力 度-真歪度関係における骨格曲線は、一方向載荷試験で得られた真 応力度-真歪度関係と良い対応を示すことが知られている。また、 低降伏点鋼・極低降伏点鋼においても、この関係が成り立つことは 報告されている ${ }^{10 \%}$ 。本実験で用いた各試験体の真応力度-真歪度関 係から抽出した骨格曲線を、真応力度-真歪度関係に置換した素材
試験結果と比較し、図-7にに示す。LYP225 では、素材試験結果にお いて上降伏点に達した後急激に耐力が低下しているのに対し、綝返 し載荷実験から得られた骨格曲線では降伏後さほど耐力が低下して おらず、降伏棚近傍における対応はあまり良くないが、全体的に見 ればいずれの鋼材も骨格曲線は一方向載荷試験である素材試験の結 果と概ね対応している。本研究では、骨格曲線は素材試験結果で代 表するものとして、バウシンカー部のみをモデル化する。

2.5 バウシンガー部のモデル化

履歴曲線中に現れるバウシンガー部の形状については、その段階 までに鋼材が受けた履歴の影響を受けることが報告されている を。本研究では、ダンパー用鋼材の真応力度-真歪度関係におけるバ ウシンガー部を、文献 8)における鋼部材の履歴モデル同様、バイ リニア型の簡潔なモテルルで表現することを試みた。バイリニア型の 履歴モデルを規定する変数のうち、骨格復帰点における応力度 $\sigma_{B S}$ は引張側・圧縮側それぞれについての前サイクルまでに経験した最 大応力度であり、立ち上がり剛性は弾性除荷部との連続性から弾性 剛性とした。従って、実験結果に基づくバイリニア型のモデル化に 必要な変数は、バウシンガー部における塑性歪の進展 $\Delta_{1} \varepsilon_{B}$ と、剛性 変化点における応力度の骨格復帰点における応力度、的にに対する比 率的である。

このうち、バウシンガー部における塑性歪の進展 $\Delta_{\text {、 }}$ につつて、 実験で得られた各サイクルでの $\Delta_{A} \varepsilon_{B}$ と、そこに至るまでの骨格曲線 での累積丕 $\sum \Delta_{1} \varepsilon_{S}$ の関係で、LYP100 について図-8(1)に、LYP225 について図-8 (2)に示す。両者の間にはややばらつきは見られるも のの、全体的に見れば LYP100 については式(3)で、LYP225につい ては式(4)で表される線形関係が概ね成り立っている。なお、LYP225 においては、載荷初期に比較的大きな歪振幅(1\%以上)を与えた場合 にバウシンガー部における歪の進展が小さくなっている。

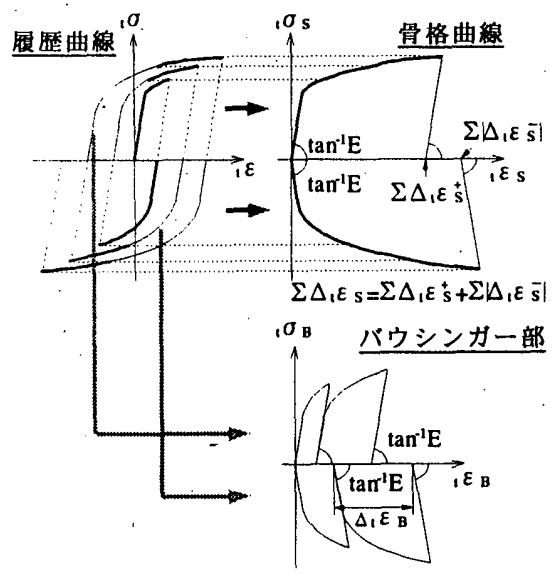

图-6 履歷曲線の分解

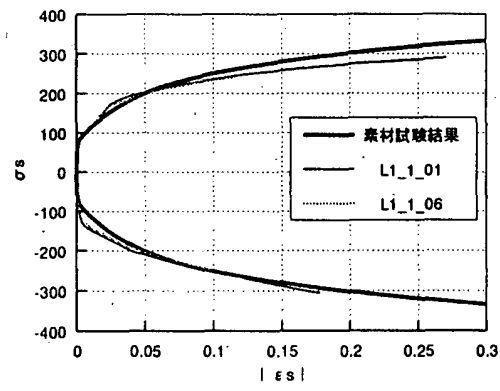

(1) LYP100(1)

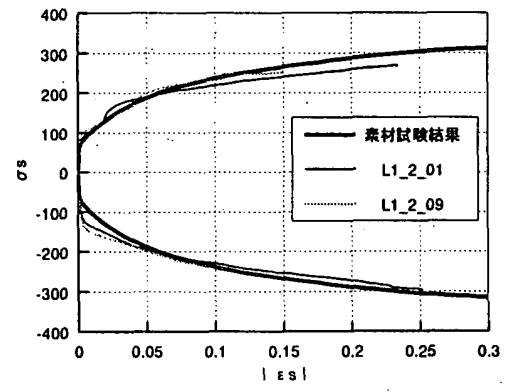

(2) LYP100(2)

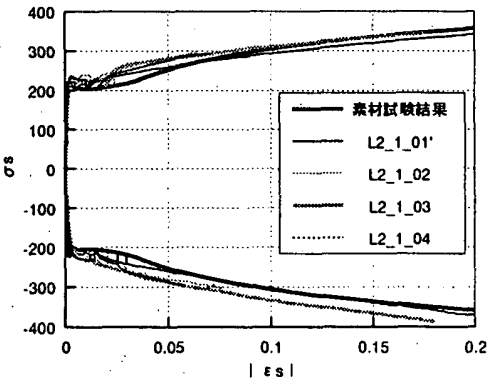

(3) LYP225(1)

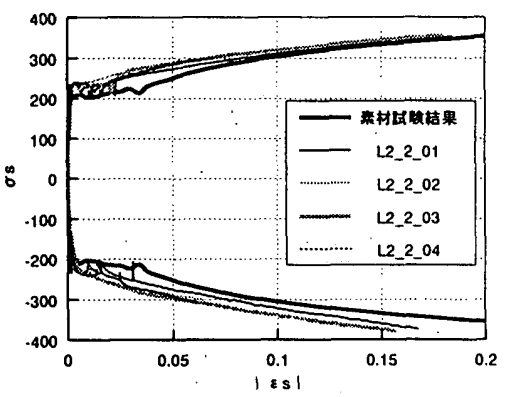

(4) LYP225(2)

図-7 骨格曲楾の対応 
LYP100について

$\Delta_{t} \varepsilon_{B}=0.125 \sum \Delta_{t} \varepsilon_{s}$

LYP225について

$\Delta_{t} \varepsilon_{B}=0.2 \sum \Delta_{t} \varepsilon_{s}$

(4)

またバウシンガー部の剛性変化点における応力度の骨格復帰点に おける応力度 $O_{B} S$ に対する比率 $a_{B}$ については、図-9に示すように、 骨格復帰点までにバイリニア型の履歴モデルで吸収する歪エネルキ 一と、実験結果においてバウシンガー部で吸収した歪エネルギーが 一致するように求めた。実験結果から求めた $\alpha_{B}$ の值を、 $\Delta_{1} \varepsilon_{B}$ との 関係で，LYP100について图-10(1)に、LYP225について图-10(2) に示す。 $a_{B}$ と $\Delta_{1} \varepsilon_{B}$ の間には、LYP100では $\Delta_{I} \varepsilon_{B}$ の小さな領域におい て右眉上がり傾向が見られるが、いずれの鋼材にも共通の值として、 式(5)で表した。

$$
a_{B}=0.85
$$

\section{6 履歴モデルと実験結果の比較}

以上のように簡潔にモデル化したバウシンガー部の履歴モデルを 用いて、繰り返し軸応力を受けるダンパー用鋼材の履歴挙動のモデ ル化を行った。この履歴モデルは、骨格曲線、バウシンガー部、弾 性除荷部により構成され、バウシンガー部の形状を規定する係数で ある $\Delta_{1} \varepsilon_{B}$ と $a_{B}$ の值を除けば、文献 8$)$ で提案された鋼部材の履歴乇 デルと基本的に同じものである。骨格曲線については、一般に履歴 曲線から抽出された骨格曲線が単調載荷時の真応力度-真歪度関係

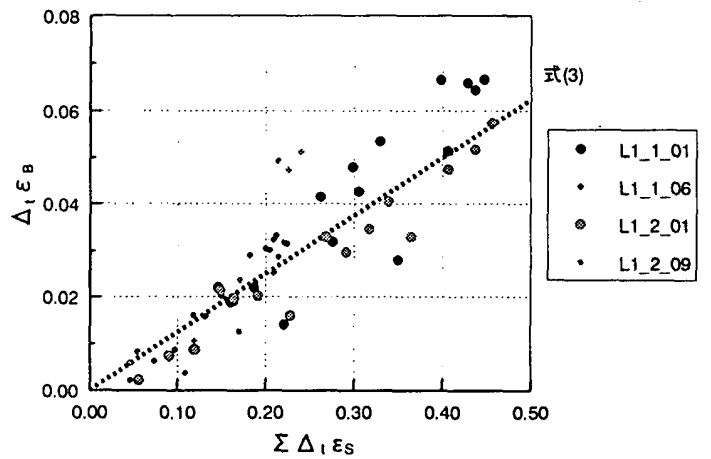

(1) LYP100

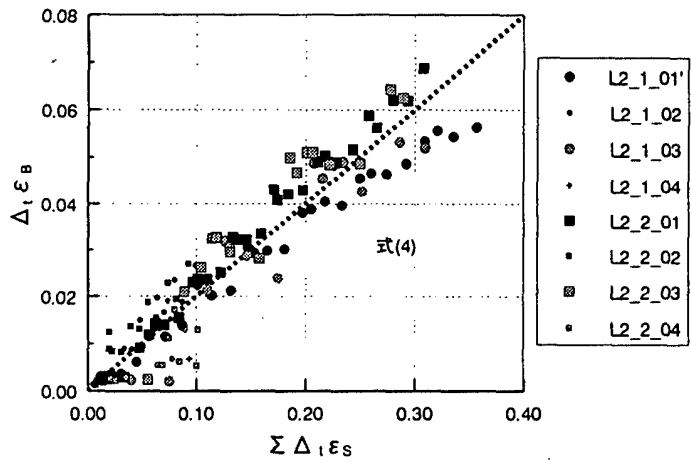

(2) LYP225

図-8 バウシンガー部における塑性歪の進展 $\Delta_{i} \varepsilon_{B}$ と 骨格曲線での累積丕 $\sum \Delta_{t} \varepsilon_{S}$ の関係
と良い対応を示す 5. 6tなこことが知られていることから、真応力度-真 歪度関係に置換した素材引張試験結果を用い、弾性除荷部について は弾性剛性を、バウシンガー部については前節で構策したモデルを 用いる。ただし、初期降伏以降最初に逆側の応力領域に移る部分は、 バウシンガー効果により比例限が低下するバウシンガ一部としての 挙動を示すが、正負それぞれの領域において、初めて達する荷重レ ベルにおける履歴曲線の増分をつなぎ合わせたものを骨格曲線とす

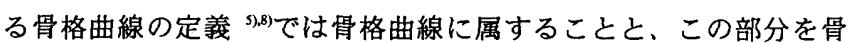
格曲線として作図した場合に単調載荷時の真応力度-真歪度関係と 良い対応を示す 示すように、骨格復帰点に相当する $\Delta_{1} \varepsilon_{B}$ の塑性歪が生じる点に至る までの区間をバウシンガー部のモデルで置き換えた。

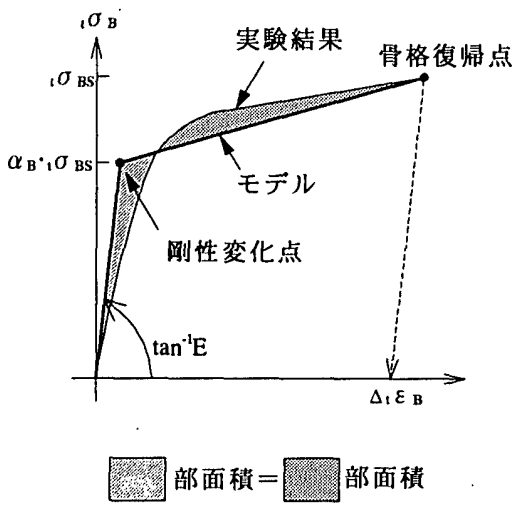

図-9 バウシンガー部における剛性変化点

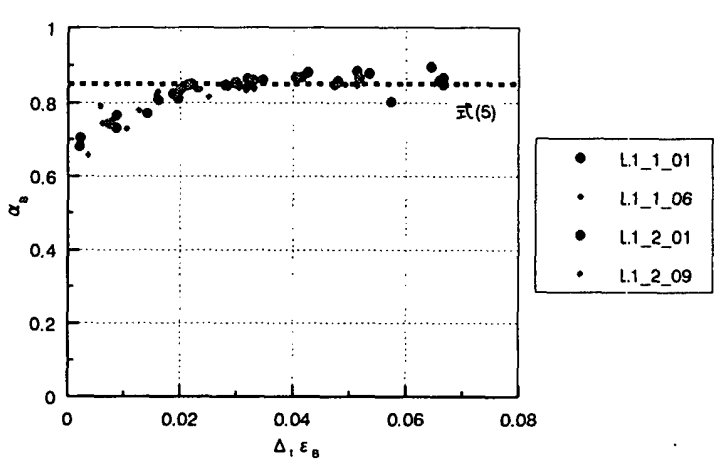

(1) LYP100

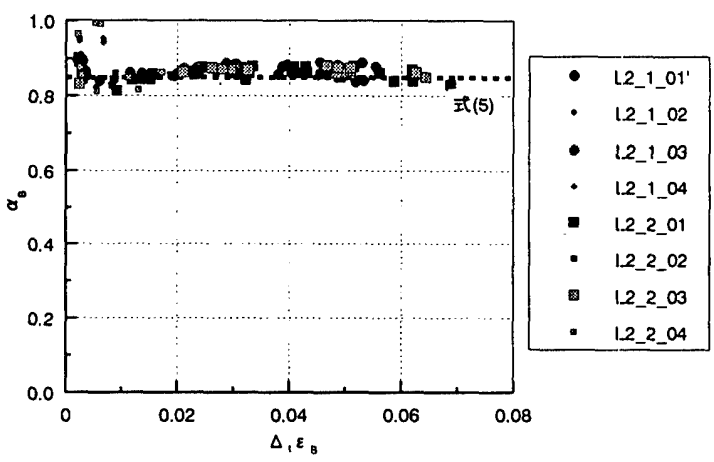

(2) LYP225

図-10 $a_{B}$ と $\Delta, \varepsilon_{B}$ の関係 
本履歴モデルについて、実験と同じ丕履歴を与えた結果を実験結 果と比較し、図-12に示す。また、各半サイクルでのピーク歪到達 時での骨格曲線における累積歪と履歴吸収歪エネルギーについて、 実験結果と履歷モデルを比較し、それぞれ図-13、図-14に示す。

まず履歴曲線の形状であるが、LYP100 については、実験結果と 履歷モデルは良い対応を示している。一方 LYP225については、繰 返し載荷実験では素材試験結果で見られたような降伏点に達した後 の急激な酎力の低下が見られなかったことから、累積歪の小さな領 域においては実験結果に対して履歴モデルの応力が低くなる傾向が 見られる。特にランダムな歪履歴を与えた L2_1_04ならびに L2_2_04については、与えた累積の歪量が他の試験体と比べて小さ いことから、全体的に対応が悪い。しかしながら、全試験体につい て累積歪の大きな領域まで見れば、実験結果と履歴モデルは概ね対 応していると言えよう。また、鋼材の指標となる骨格曲線における 累積歪と、履歴吸収歪エネルギーの履歷においては、両鋼種とも実
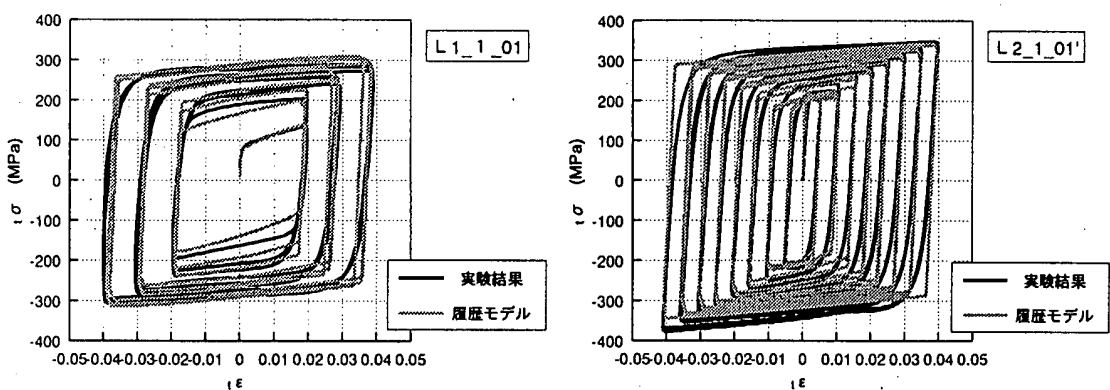

図-11 初期降伏後の挙動
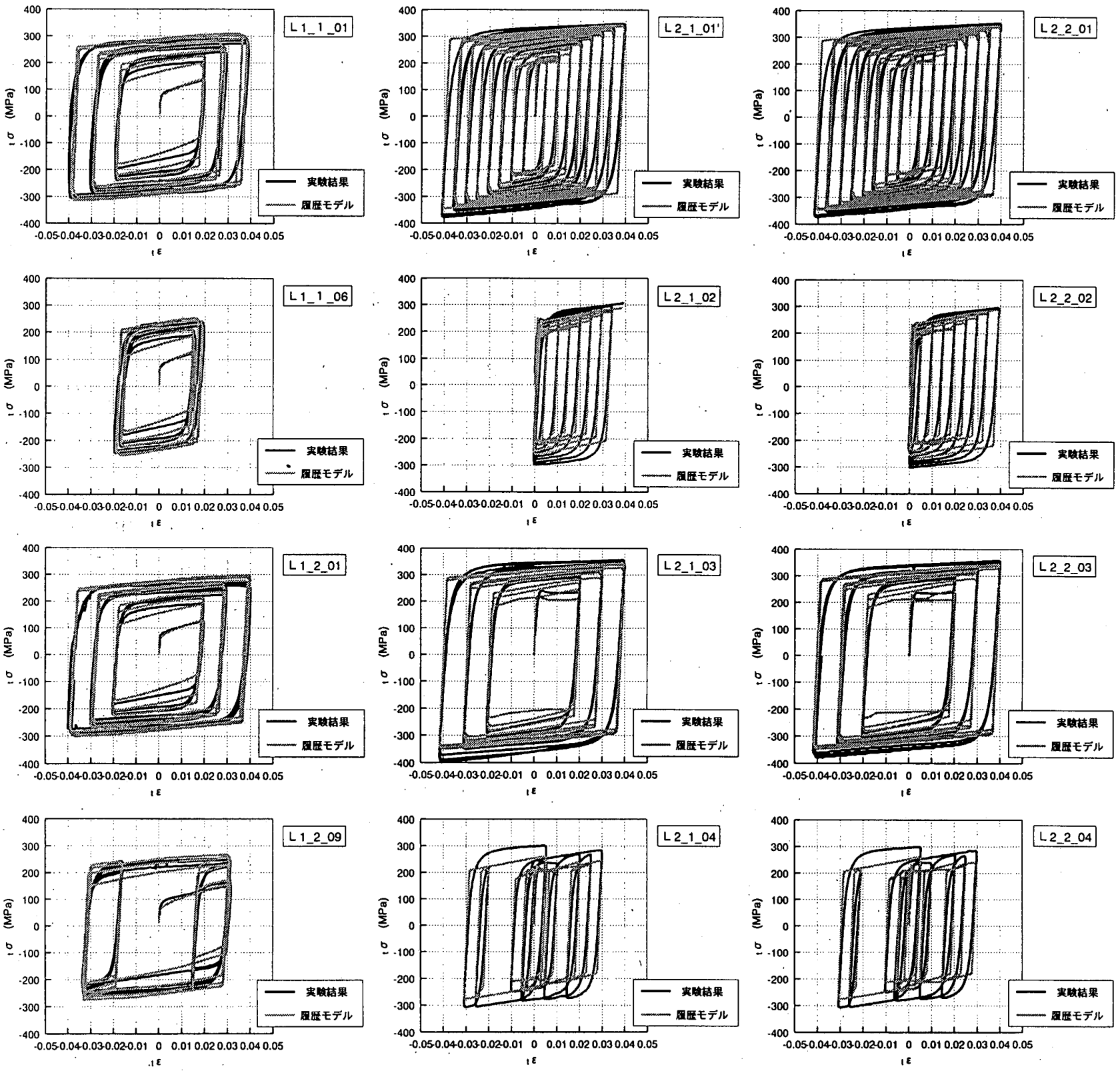

図-12 実験結果と履歴モデルの比較 


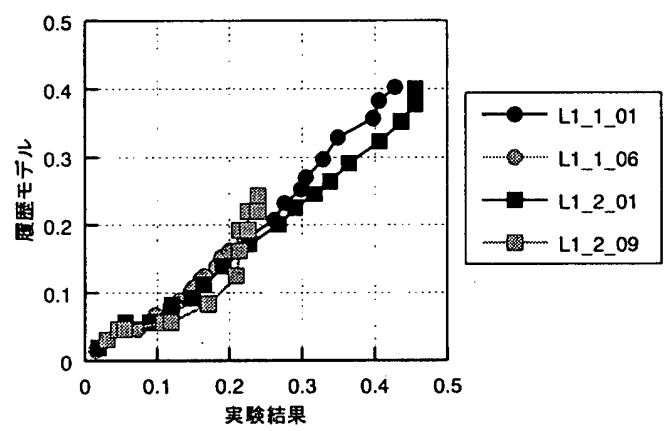

(1) LYP100

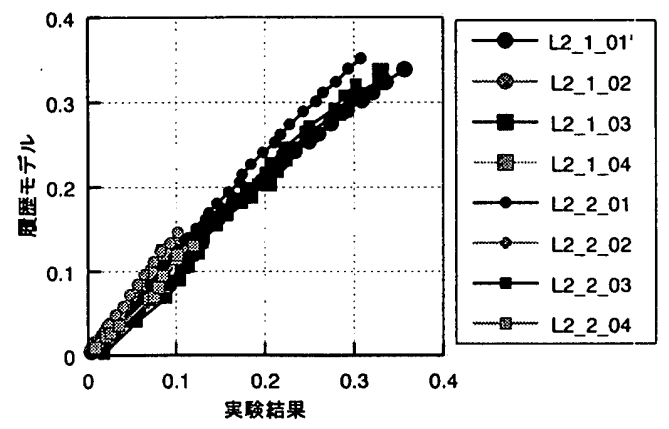

(1) LYP225

図-13 骨格曲線における累積歪の比較

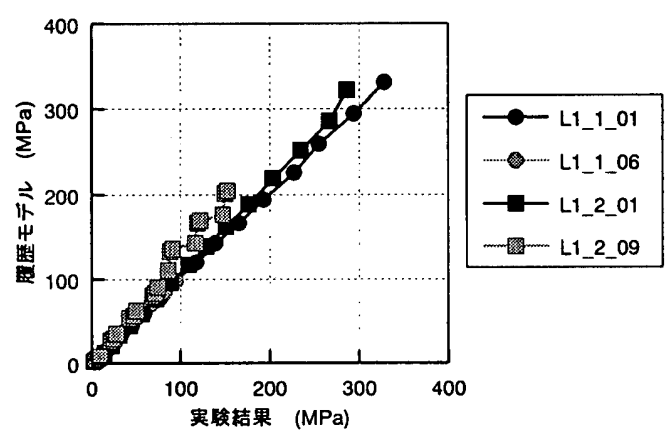

(1) LYP100

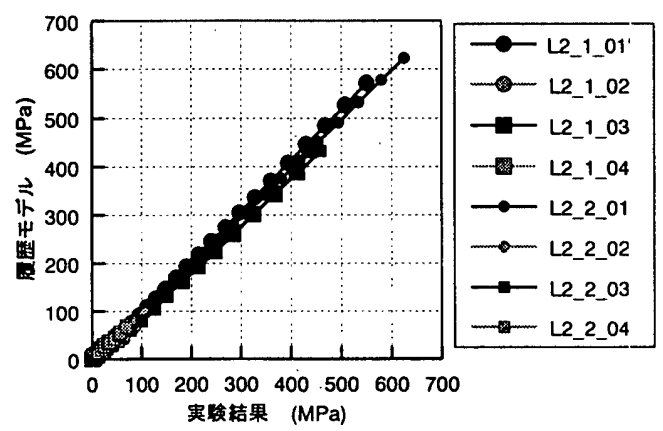

(1) LYP225

図-14 履歴吸収歪エネルギーの比較

\section{3. 鎠種の違いによる履歴举動の比較}

本研究では、ダンパー用の鋼材である極低降伏点鋼 LYP100 およ び低降伏点鋼 LYP225について軸方向繰り返し載荷実験を行い、実 験結果に基づき真応力度-真歪度関係におけるバウシンガー部をバ イリニア型にモデル化した。ここでは LYP100、LYP225 だけでな く、既報》で扱った SN400も併せて比較し、一般に履歴型ダンパー に用いられている鋼材の、鋼種による履歴挙動の違いを考察する。

まず、バウシンガー部における塑性歪の進展 $\Delta_{1} \varepsilon_{B}$ であるが、いず れの鋼種においてもそこに至るまでの骨格曲線での累積丕 $\sum \Delta_{1} \varepsilon_{s}$ と の間に線形関係が概ね成り立っており、その関係は

$$
\begin{array}{ll}
\text { LYP100 について } & \Delta_{t} \varepsilon_{B}=0.125 \sum \Delta_{t} \varepsilon_{s} \\
\text { LYP225 について } & \Delta_{t} \varepsilon_{B}=0.2 \sum \Delta_{t} \varepsilon_{s} \\
\text { SN400 について } & \Delta_{{ }^{\prime}} \varepsilon_{B}=0.33 \sum \Delta_{t} \varepsilon_{s}
\end{array}
$$

となっている。骨格曲線での累積歪 $\sum \Delta_{1} \varepsilon_{s} に$ 掛かる係数が小さいほ ど、繰り返し荷重下における累積歪においてバウシンガー部の占め る割合が小さくなり、骨格曲線の占める割合が大きくなる。骨格曲 線における累積歪は鋼材の損傷の指標であり、累積歪に占める骨格 曲線の割合が大きいということはそれだけ損㑥が溜まりやすい、換 言すると繰り返し荷重を受けた場合に、破断限界に近づきやすい性

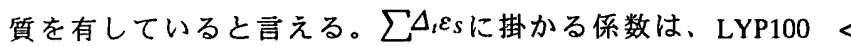
LYP225 < SN400 となっている。今回の実験および既報”での素材 試験において、破断伸びは LYP100 > LYP225 > SN400 (JIS-1A 号試 験片でそれぞれ $45 \%$ 程度、40\%程度、35\%程度)であったが、載荷
履歴によっては破断に至るまでの累積丕が逆転する可能性がある。

一方、バイリニア型にモデル化したバウシンガー部の，剛性変化 点における応力度の骨格復帰点における応力度 $\sigma_{B S}$ に対吉る比率 $a_{B}$ であるが、その值が大きいほどバウシンガー部での軟化の程度が低 く、エネルギー吸収のロスが小さくなることを意味する。 $a_{B}$ の值 は、いずれの鋼種においても。ほぼ一定值となっているおり、SN400 で 0.67 であるのに対して、LYP100 および LYP225 では 0.85 と高く なっている。バウシンガー部における塑性歪の進展 $\Delta_{1} \varepsilon_{B}$ の骨格曲線 での累積丕 $\sum \Delta_{1} \varepsilon_{s}$ に対する比率が小さいことと併せて、怟降伏点釷 ならびに極低降伏点鋼は、一般の構造用鋼材に比べてバウシンガー 部におけるエネルギー吸収のロスが小さい鋼材であると言える。

既往の研究 "においては、低降伏点鋼ならびに極低降伏点鋼は SS400 材に比べ非常に大きな破断延性を有するにも関わらず、どち らかというと降伏点の低い材種において疲労寿命が短くなる傾向が あることが報告されている。バウシンガー部における塑性歪の進展 $\Delta_{i} \varepsilon_{B}$ のそこに至るまでの骨格曲線での累積歪 $\sum \Delta_{t} \varepsilon_{S}$ に㳔する比率 は、この知見を裹付ける結果となっている。また、筆者らが以前行 った座届拘束ブレースを組み込んだ実大部分骨組の振動台実験 ${ }^{22} に$ おいても、SN400を芯材とした座屈拘束ブレースを組み込んだ骨組 の方が、LYP100 を芯材とした平行部長さの等しい座㐿拘束ブレー スを組み込んだ骨組に比べ、座屈拘束ブレース芯材の破断に至るま でに、より多くの加振に耐えた。この実験では、破断に至るまでの 芯材の累積歪は、SN400 を用いた座屈拘束ブレースでは LYP100を 用いた座届拘束ブレースの 1.5 倍以上 ${ }^{13)}$ であった。もっとも、いず 


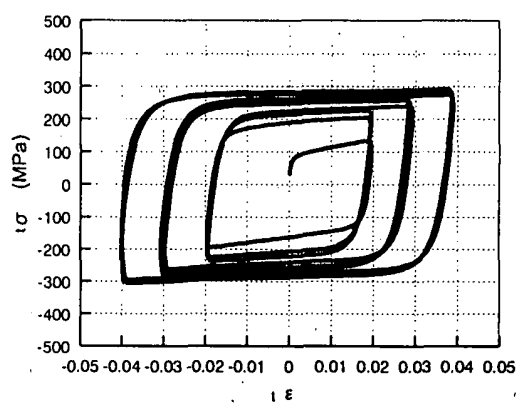

(1) L1_1_01(LYP100)

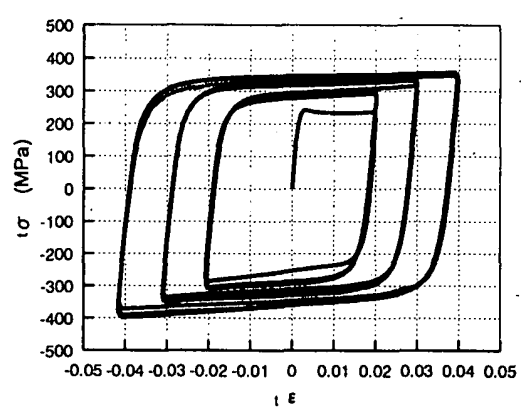

(2) L2_1_03(LYP225)

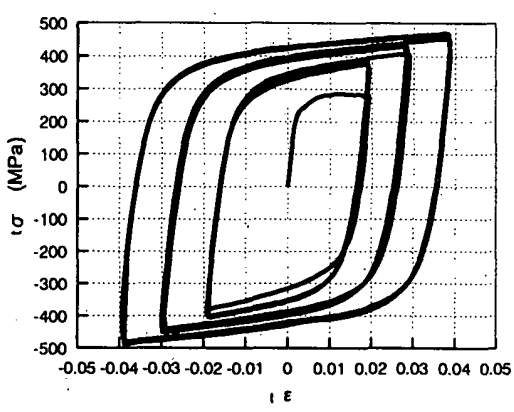

(3) SN_10") (SN400)

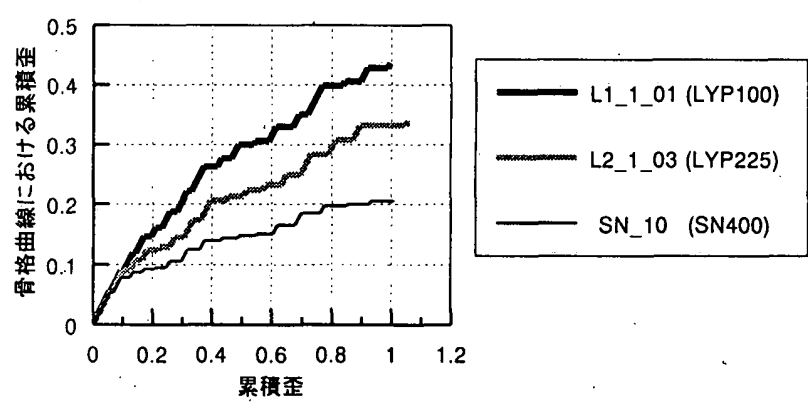

(4) 骨格曲線における累積歪

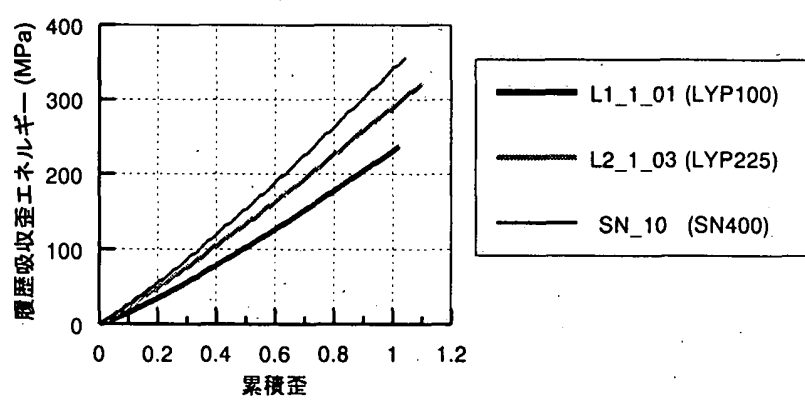

(5) 履歴吸収歪エネルギーの比較

図-15 同じ載荷履歴で行った鋼種の異なる試験体の実験結果の比較

れの試験体についても、Level2 相当を想定して設定した入力をさら に上回る入力を複数回行った後に破断に至ったものであり、座屈拘 束ブレースの芯材としての変形能力には全く問題は無い。むしろ、 座屈拘束ブレースが実際に機能する程度の丕レベルにおいては、耐 力が低いことで小さな歪レベルからエネルギー吸収能力を発揮する だけでなく、除荷時に解放される弾性歪エネルギーが小さいこと、 そしてバウシンガー部の占める割合が小さいことで効率の良いエネ ルギー吸収性能が期待できることから、安定した塑性歪エネルギー の吸収が求められるダンパー用の鋼材としては LYP100 の方が SN400より適していると考えられる。

ここで、本章で比較検討する 3 つの鋼種(LYP100、LYP225 およ びSN400)について、同じ載荷履歴で行った実験の結果(L1_1_01, L2_1_03，SN_10")を、图-15に示す。(1)〜(3)がそれぞれの試験体の 履歷曲線であり、(4)は累積歪と骨格曲線における累積歪の関係、(5) は寒積歪と履歴吸収歪エネルギーの関係である。

履歴曲線の形状であるが、バウシンガー部のモテル化の過程で明 らかになったように、LYP100 と LYP225 ではバウシンガー部にお ける軟化の程度は低く、完全弾塑性型に近い形状となっているのに 対し、SN400 ではバイリニア型の形状となっている。また、降伏点、 降伏比ともに低い LYYP100では、載荷初期と履歴曲線が安定してか ら以降では、耐力に大きな隔たりが見られる。一方、降伏点の高い SN400 では、塑性化に伴うエネルギー吸収量も大きいが、除荷域に

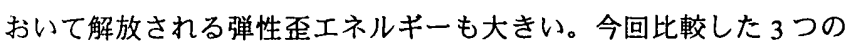
鋼種の中で、載荷初期から耐力、履歴曲線の形状とも安定している のは、降伏比が高くバウシンガー部における軟化の程度も低い LYP225ということになる。
また、骨格曲線における累積丕については、履歴モデルにおける 係数からも明らかなように、LYP100 がもっとも大きく、次いで LYP225、そして SN400 の順となった。これは、既往の研究 ${ }^{11,12}$ で 報告されている、絽り返し荷重を受ける場合に大きな破断延性を有 する降伏点の低い鋼材の方が早期に破断することを裏付けるもので ある。

一方、履歴吸収歪エネルギーについては、耐力が高いこともあり、 SN400 が最も大きく、次いで LYP225、最小は LYP100 と耐力の順 となった。いずれの鋼種についても、載荷初期から載荷終了に至る まで、安定したエネルギー吸収能力を発揮していることがわかる。

\section{4. 結論}

履歴型ダンパー用の鋼材として多用される極低降伏点鋼 LPY100 および低降伏点鋼 LYP225について、載荷履歴をパラメーターとし た軸方向繰り返し載荷実験を行い、真応力度-真歪度関係を、バウ シンカー効果を考慮した簡潔な表現でモテル化した。この履歴モデ ルは、既往の研究 ${ }^{8}$ で提案された部材レベルにおける簡潔な履歴モ テルを、前報”において構造用鋼材の真応力度-真歪度関係に応用し たものであり、極低降伏点鋼および低降伏点鋼に適用するにあたつ て、鋼材特有の係数を実験結果から求めたものである。実験と同じ 歪履歴を与えた履歴モデルを実験結果と比較したところ、両者は損 傷の指標となる骨格曲線における累積歪や履歴吸収歪エネルギーを 含め、概ね良い対応を示した。本履歴モデルは簡潔なものではある が、塑性域で繰り返し荷重を受ける履歴型ダンパーの挙動を評価す る上では十分有効であろう。

また、LYP100、LYP225 だけでなく SN400 も併せて、一般にダ 
ンパーに用いられている鋼材について、鋼種による履歴挙動の違い を比較したところ、バウシンガー部における塑性歪の進展 $\Delta_{1} \varepsilon_{B}$ のそ こに至るまでの骨格曲線での累積歪 $\sum \Delta_{1} \varepsilon_{s}$ に対する比率が、 LYP100 < LYP225 < SN400 となっていた。この比率が小さいほど、 紹り返し荷重下における累積歪において、バウシンガー部の占める 割合が小さく、鋼材の損傷の指標である骨格曲線の占める割合が大 きくなる。即ち、今回比較した 3 つの鋼種の中では、降伏点が低い 鋼材ほど破断限界に近づきやすい性質を有していることが履歴モデ ルの特性の中で明らかとなった。これは、既往の研究で報告されて いる実験結果 ${ }^{11 .}{ }^{12)}$ を裏付けるものである。もっとも、履歴型ダン パーは鋼材の破断限界に比べかなり小さな昰レベルで用いられてお り、破断限界に至るまでの変形能力はほとんど問題にはならない。 破断が問題とならないとすれば、耐力が低いことで除荷時に解放さ れる弾性歪エネルギーが小さいだけでなく、バウシンガー部におけ る塑性歪みの進展が小さくかつバウシンガー部における剛性変化点 の応力が高いことから、バウシンガー部におけるエネルギー吸収の ロスが小さく効率の良いエネルギー吸収性能が期待できる低降伏点 鋼 LYP225 や極低降伏点鋼 LYP100 の方が、ダンパー用の鋼材とし て適した性質を持っていると考えられる。さらに、降伏点・降伏比 ともに低い極低降伏点銿 LYP100 では、載荷初期と履歴曲線が安定 してから以降では耐力に大きな隔たりが見られるが、降伏比が高く バウシンガー部における軟化の程度も低い低降伏点鋼 LYP225 は載 荷初期から耐力、履歴曲線の形状とも安定しており、今回比較した 鍓材(LYP100,LYP225,SN400)の中では、安定したエネルギー吸収が 求められるダンパー用の鋼材としては最も適していると言える。

\section{謝辞}

本研究で用いた試験体に用いた鋼材は、新日本製鐵(株) 建築事業 部からご提供いただいた。LYP100 の実験は、元東京工業大学大学 院生 山口路夫(現新日本製鐵)、同 竹内百合(現構造計画研究所)、 同今枝知子(現国土交通省)の各氏によって行われたものである。 また、本論文の作成にあたっては、東京工業大学大学院生 鄭 景 洙氏に作業を手伝っていただいた。ここに記して謝意を表す。

\section{参考文献}

1)秋山 宏: 建筑物の耐霞極限設計 第 2 版, 東京大学出版会, 1987

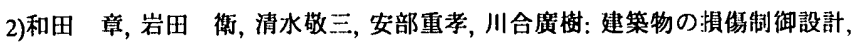
丸善, 1998

3)小野徹郎, 上之组貴重, 吉田文久, 岩田 徨, 林賢一: 金属系素材の素材特 性及び展歴举動に関する研究，日本建築学会棰造系詥文集，第 498 号， pp.137-143, 1997.8

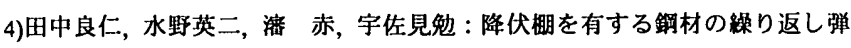
塑性モデル - 二曲面望性モテルのの開発 -, 土木学会 楧造工学論文集 A, Vol.37A, pp.1-14, 1991

5)加藤 勉, 青木博文，山内泰之: 引張・压縮練返し荷重を受ける銅素材の挙 動に関する実験的研究, 日本建築学会大会学術講演梗概集, pp.803-804, 1970.9 6)加藤 勉, 秋山 宏, 山内泰之: 鎆材の応力-ひずみ履歴曲線に関する実験則, 日本建筑学会大会学術講演梗概集, pp.937-938, 1973.10

7)山田 括，今枝知子，岡田 健: バウシンガー効果を考虑した棈造用鎆材の

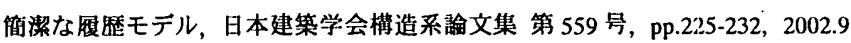
8)秋山宏，高橋 䙘: 铜權造剛接骨組の耐震性に及ぼすバウシンカー効果の 影鳘, 日本建筑学会構造系論文報告集, 第 418 号, pp.49-57, 1990.12 9)山田 哲, 山口路夫, 竹内百合, 竹内 徹, 和田 章: 動的練り返し載荷实験 に基づくダンパー用銅材の履歴特性の种洒 速度依存性を考虑したダンパー 用銅材の履歴特性に関する研究その 1 ， 日本建築学会槽造系淪文集 第 553 号, pp.121-128, 2002.3

10)佐伯英一郎, 杉沢 充, 山口種美, 望月晴雄, 和田 章: 低降代点鎆のヒステ リシス及びヒステリシスエネルキー， 日本建学学会構造系論文集 第 473 号, pp.159-168, 1995.7

11)佐伯英一郎, 杉沢 充, 山口種美, 望月晴雄, 和田 章: 低降伏点銅の低サ1 クル疲学特性に関する研究, 日本建筑学会構造系論文集 第 472 号, pp.139-147, 1995.6

12)山口路夫, 山田 哲, 松本由香, 谷川敬祐, 小野森司, 竹内 微, 小川信行, 秋 山宏：座屈拘束ブレースを有する損僨制御構造部分骨組の実大振動台実匼， 日本建築学会權造系論文集 第 558 号, pp.189-196, 2002.8 13)山口路夫: 座屆拘束ブレースを有する銅構造骨組の実大振動台実䮦, 東京 工業大学博士論文, 2002.6 